Article

\title{
Political Economy, Capitalism and Sustainable Development
}

\section{George Liodakis}

Department of Sciences, Technical University of Crete, 73100 Chania, Greece;

E-Mail: liod@science.tuc.gr; Tel.: +30-2821-037-317; Fax: +30-2821-037-843

Received: 13 July 2010; in revised form: 5 August 2010 / Accepted: 10 August 2010 /

Published: 18 August 2010

\begin{abstract}
After a critical review of conventional approaches to sustainability, this paper contrasts orthodox (neoclassical) economic theory with a political economy approach, arguing that such an approach focusing on the historically specific organizational form of production and the inherent characteristics of the capitalist mode of production is crucial for exploring the preconditions, the content and the prospects of sustainability. Analyzing briefly these characteristics and the developmental trends of capitalism, we locate the basic causes behind the currently exacerbated economic and ecological crisis, and on these grounds we briefly explore the required systemic transformations necessary to ensure a socially and ecologically, truly sustainable development.
\end{abstract}

Keywords: political economy; Marxist theory; capitalism; sustainability conditions; sustainable development

\section{Introduction}

It would be expected that sustainability should be a major concern of any social formation or socioeconomic system. Any society, in other words, should take care to ensure the conditions for its reproduction and viability. The ecological conditions of sustainability, in particular, should be a primary concern as a precondition for this reproduction and viability. On the other hand, it is commonly the case that the human impact upon the ecological environment is largely determined by the specific social structure, the social relations among people, and the material/social relations of people with nature. However, for definite reasons, several societies have historically, for a long time and with detrimental effects, ignored these ecological preconditions of social reproduction. 
In the history of capitalist societies, the ecological conditions of social reproduction have been largely ignored or downplayed, and it was only the exacerbating ecological crisis during recent decades that has forced economists, policy makers and the common public to pay more attention to natural limits and the conditions of sustainability. This growing ecological awareness has stimulated multifaceted environmental movements and led to an extensive literature concerning both theoretical analysis and the implementation of relevant policies to ensure a sustainable development. It seems paradoxical however that, while sustainability appears as a hardly controversial goal, yet opposed social forces dispute the causes of ecological degradation and crisis, as well as the specific policies intended to ensure the conditions of sustainability [1].

The concept itself of sustainable development, which came to the fore mainly with the so-called Brundtland Report (1987), has been framed within the dominant ideology and the mainstream economic theory. Within the framework of orthodox (neoclassical) economics, in particular, this idea has been largely perverted to signify a mere (quantitative) compromise between economic growth and the need of environmental protection [2]. As a result, the prevalent conception of sustainable development has raised an extensive and heated debate concerning both the theoretical foundations of this conception and the policies aiming at the implementation of such a sustainable development. Extensive criticisms of this prevalent conception have been addressed both from a liberal mainstream or a neo-Malthusian view [3-6] and a more radical or Marxist standpoint [1,7-11]. Important questions have been raised in this literature concerning the content itself of sustainability, and more specifically, whose sustainability, what type of natures are to be sustained, through what processes, and for whose benefit? Quite apart from the mainstream conception of sustainability, focusing almost exclusively on the sustainability of capitalist profits, some of this literature considers sustainability as a form of resistance or a catalyst for social change. It moreover considers sustainability as encompassing three very important dimensions - economic prosperity, social equity, and environmental integrity [1]. As all these three aspects of sustainability are intrinsically interrelated and decisively determined by the prevailing mode of production, I will try to show in this article that the prevailing capitalist mode of production fails to ensure the conditions of sustainability in all these respects.

The purpose of this article is not to offer a detailed critical review of the relevant literature. I will rather stress that, both the conventional conception of sustainable development and related approaches to the environmental problem, such as neo-Malthusianism, zero-growth or de-growth, eco-regulation and green development, mechanistically separate production or development (growth) from the environment (or nature) and then try to superficially compromise them, while totally ignoring the historically specific organization of social production and the dialectic between society and nature that it gives rise to. I will moreover argue that, as the process and the particular mode of production is of primary importance for the relation between society and nature, as well as for the impact on the environment, our specific understanding of the economic question (or problem) and the social organization as largely determined by the mode of production are also crucial for exploring the causes of ecological crisis and the conditions of ecological and social sustainability. In this sense, I will compare and contrast in the next section orthodox (neoclassical) economics with political economy, focusing more on Marxist political economy, and drawing at the same time the relevant ecological and social implications in each case. The basic features of the capitalist mode of production (CMP) will be examined in a third section, where an attempt is made to explain the specific society-nature relation 
and the causes of ecological crisis under capitalism. In Section four, the question of capitalism's sustainability is more specifically addressed, focusing on the prospects of resolving the currently exacerbated ecological and economic crisis. The article concludes with an exploration of the social requirements for an ecologically and socially sustainable development.

\section{Economics and Political Economy}

\subsection{Economics: Social and Ecological Implications}

As is familiar, orthodox (mainstream) economists conceive the basic economic question or problem as a problem of coordination between a given productive capacity of society, determined on the basis of accumulated productive means and a bounded endowment in natural resources, and the increasing and insatiable social needs [12,13]. It is usually assumed that this coordination is achieved in the best possible way through the market mechanism which ensures maximum social welfare. With the aid of mathematical formalism, it is more specifically considered that the economic problem is merely a (dual) optimization problem (maximization of social welfare or minimization of resource use) under certain constraints. This broad setup of the economic problem is considered in a historically abstract level, and on this level there is no question that all societies are indeed characterized by a certain productive capacity, have a set of social needs and some social mechanism to achieve the required coordination between the two sides. This abstract formulation, however, leads mainstream economists to a failure to specifically and adequately understand the expansion of productive capacity and the actual determination of social needs, while at the same time, blindly attached to the market mechanism, they fail to consider other possible mechanisms of economic coordination. That is why the prevailing neoclassical orthodoxy, which constitutes a degenerative evolution of the classical (bourgeois) political economy, has essentially an un-historical character and its main focus is on the production and exchange of economic goods, in general, and not of commodities more specifically. This so-called economics discipline also abstracts from any class divisions or social contradictions, and thus from any phenomena of class exploitation. Such a classless approach merely distinguishes between producers (private firms) or investors and consumers, and based on methodological individualism searches for the economic conditions or behavioral attitudes that presumably ensure welfare maximizing results. This type of economics, moreover, totally abstracts from power relations and the specific role of social institutions. It is only in some particular trends within mainstream economics (such as institutionalism or evolutionary economics), which occasionally move on the margin of heterodoxy, that some conflicts of interest and the role of institutions are partly, even if inadequately, taken into account.

With regard to the external (natural) conditions of production, mainstream (neoclassical) economics usually consider nature (including all natural resources) as a normally fixed external factor to be conquered and fully utilized in the context of productive activity. Apart from other implications of this conception of nature as an external factor, it is most notable that natural resources are considered as a mere factor of production in the context of the conventional production functions used by neoclassical economists, and indeed as a homogeneous and undifferentiated input of production. This conception, along with profit maximization and an inherently competitive growth of production, lead to clear implications insofar as the overexploitation and depletion of natural resources are concerned. It is also notable that neoclassical economics commonly tend to disregard, especially in the context of the 
prevalent neo-liberalism of recent decades, both natural limits and scarcity of (natural) productive resources. As I have stressed elsewhere, “[m]ainstream researchers, under the impact of a capitalist growth triumphanlism overstressing the potential substitutability of economic resources and technologies, and ignoring some fundamental laws of nature and most significantly the second law of thermodynamics, have tended to underrate or totally ignore scarcity" [14,15]. A natural resource is commonly considered as a free good insofar as it is abundant, and "is not thought of as a resource until it is rendered scarce" [16].

It is only in the context of neo-Malthusian approaches (largely within the mainstream) that natural limits are taken into account and the fixity of natural resources is indeed overstressed, while the depletion of natural resources and the increasing environmental stress is, as we will see below, misleadingly attributed mainly to overpopulation.

As is also familiar, private property in the means of production (including natural resources) constitutes one of the fundamental prerequisites and a shibboleth of a free market system. It is moreover remarkable that mainstream economic policy in recent decades has responded to environmental degradation by extending private property rights through a further privatization of natural resources and a drastic shrinkage of the commons sector [17]. As both theoretical analysis and available evidence suggest, however, and contrary to a widely accepted belief, "private property is not a sufficient condition to ensure proper care of natural environment and the ecosystem, but it is, on the contrary, quite often a condition for the degradation of the environment or the destruction of whole ecosystems" [14]. This becomes evident in two characteristic cases. In the first case, private property of a certain natural resource (or a piece of land) usually gives an unrestricted right to the proprietor to overuse or deplete this resource, insofar as it is to his/her interest, disregarding the sustainability conditions of the surrounding ecosystem. In another case, a particular, dis-functional and perhaps outmoded regime of private property, associated with extensive "absentee ownership", may constitute a real barrier to proper land care and environmental protection.

It should further be noted that, in those extensive cases where neoclassical economics itself recognizes a "market failure", due to a sub-optimal allocation of productive resources resulting from an externalization of a considerable part of the total cost of production, state intervention is hardly adequate to correct this misallocation and market failure. Despite all state attempts and corrective policies followed for several decades, resource depletion, environmental pollution and ecological degradation continue unabated, if not exacerbated. This may be due to difficulties in readily identifying and capturing those processes leading to a diffusion of that part of production cost externalized, as well as to the class character of the state making any relevant regulation rather selective and ineffective as regards the imposition of cost internalization. Moreover, and reversing the familiar "polluter pays principle", the polluter may continue to pollute, as long as the benefit is greater than the cost of doing so, causing thus a perhaps irreversible ecological damage. Although this type of analysis regarding the diffusion of (negative or positive) externalities may be partly useful in exploring the economic and ecological implications of contemporary (capitalist) production [16,18], the market failure metaphor may also be misleading insofar as it ends up with a policy lock-in which "deprives environmental policy of the dynamic adjustments necessary for achieving sustainability" [5]. It seems after all that we do not have a mere market failure, but rather a more general failure of the whole system based on private property and profit. 


\subsection{Political Economy: The Implications for the Society—Nature Relation under Capitalism}

Contrary to the approach followed by mainstream economics, regarding the conception of the economic problem, political economy considers critically and analyzes with a different methodology both the productive conditions or capacities of society and social needs, as well as the coordination mechanism between these two sides, recognizing that, apart from traditional forms of coordination (based on kinship ties, custom or culture) and the market mechanism, social planning might offer a socially more rational type of coordination. A political economy approach, in general, takes into account the class structure of each particular society, as well as exploitation and hence social or class conflicts. It also takes sufficiently into account the role of institutions and power relations, including the state as a basic political institution, recognizing that institutions and power relations are intimately and dynamically intertwined with economic relations, and that the economic question is inextricably related to the social question. Instead of the formalistic marginal analysis of neoclassical economics, it focuses on a search for the historically specific laws or the tendencies characterizing each particular form of social organization. It is within such a methodological context that the question is posed as to who and how is it decided what is to be produced, by what means (productive resources and technology), and for whom.

Leaving aside other trends in political economy, I will focus on the Marxist approach, as a theoretically more adequate and historically more influential approach, again abstracting from particular trends within a broadly conceived Marxist approach. For the classics of Marxism and most contemporary Marxists, it is essential to start from a materialist foundation of the relation between people and nature and proceed with a historically specific exploration of the transformation of this relation. In the course of production, humans exert a purposeful effect on nature in order to extract natural use values (raw materials) and transform them into final use values suitable to satisfy certain human needs. Human labour plays a crucial mediating role in this dialectical interaction between people and nature, transforming historically both humans themselves and nature. This dialectical interaction is not understood as an external but rather as internal relation where humans themselves are part of nature. This interaction with nature is aided by produced means of production or technological artefacts, and as these latter improve, the potential of surplus-product production gives gradually rise to the institution of private property and this, in turn, to a particular class structure of society. Upon a class structured society arise particular forms of state institutions, largely serving the interests of ruling classes, and these institutions feedback on a continuous reshaping of class relations.

The mode of production concept is crucial for Marxist political economy and is more broadly accepted as a theoretical tool in analyzing socioeconomic and historical change. It can be understood as a historically specific formation of the social forces of production and the social relations of production reflected on a particular class structure, and most crucially their specific articulation and dialectical interaction prevailing over a long historical epoch. This dialectical contradiction between the forces and relations of production may adequately explain the dynamics of change and at a certain historical point the historical supersession of a particular mode of production.

In analyzing the capitalist mode of production (CMP), in particular, it should be noted that it is a mode of production based on a generalized commodity production and the exploitation of wage labour which comes from a historical process characterized by Marx and contemporary Marxists as primitive 
accumulation $[19,20]$. This process essentially refers to a process of class differentiation resulting from the dispossession of direct producers of the means of production and subsistence, which are converted into private property of an emerging capitalist class. It does not solely pertain to the historically initial phase of capitalist development, but as is well known continues today in a variety of different and often violent forms, with the active involvement of the state [14,17,20]. Capitalist production aims at the production and sale of commodities in order to maximize profits and the accumulation of capital. Capital, in Marxist political economy, is considered as a specific social relation of production reflected on a self-expanding value. Value here refers to the quantity of socially necessary abstract labour required for the production of a certain commodity. Value, as a conceptual category, and the labour theory of value are not mere theoretical constructs, but rather based on the ontological foundations and the operational logic of capital [21]. In exploring the laws governing the evolution of the CMP, the law of value is absolutely crucial. This law encompasses the socio-historical conditions under which labour takes the form of value, pertaining essentially the dialectical process between society and nature that Marx and several Marxists characterize as society - nature metabolism [18,19,22]. At the same time, it governs the resource allocation process regulated through the market and the determination of commodity values and commodity prices based ultimately on the corresponding values [21]. As this law reflects capital's own logic, it tends to valuate (and minimize the cost of) only those elements of production, including wage labour and marketed raw materials or inputs of production, that capitalists have to pay for, while grossly underestimating or totally ignoring the contribution of those elements, such as indigenous lay knowledge or natural forces, for which they pay nothing, or close to nothing.

It becomes already obvious from above that the historically specific organization of production (the CMP) makes a great (qualitative) difference in what regards both the society-nature relation under capitalism and the conceptualization of the economy (the economic question), which cannot be conceived as divorced but rather deeply embedded in society. It implies that private property and the dispossession of the majority of direct producers entail a growing alienation and estrangement from nature, while wage labour entails the alienation of the working people. Marxist theory can also adequately analyze the imperatives and trends of capitalist production, explain the relations of distribution based on the prevailing relations of production, and explore the determination or manipulation of social needs under capitalism [23,24]. All these may have significant implications for the society-nature relation and the ecological impact of production. Although we will specifically focus on the ecological ramifications of the basic features of the CMP in the next section, it is worth noting here that, contrary to A. Smith who considered as a self-evident fact and asserted that "consumption is the sole end and purpose of all production" [25], Marx correctly argued that the immediate "end and purpose" of capitalist production is the accumulation of surplus value (the source of profit) [26]. Consumption may have been the direct purpose of production under pre-capitalist modes of production, but under capitalism consumption is significant only insofar as the commodities produced need to be sold, with profit maximization being the immediate and dominant purpose of production. This remark has significant, both social and ecological implications.

Apart from this crucial theoretical difference, some researchers have correctly pointed out that Marx was one of the most important forerunners of the ecological movement and the idea of sustainable development $[22,23]$. Along with other researchers, he stressed that international trade, urbanization (the town/ country polarization more specifically) and technology have been among the 
most important factors contributing, not only to a rising alienation and estrangement of people from nature, but also to an increasing depletion and material scarcity, and a growing metabolic rift. According to some contemporary Marxists, "[t]he social metabolic order of capitalism is inherently anti-ecological, since it systematically subordinates nature in its pursuits of endless accumulation and production on ever larger scales" [27]. Where Marx himself was most clear on the idea of sustainability is the following passage:

"From the standpoint of a higher economic form of society, private ownership of the globe by single individuals will appear quite as absurd as private ownership of one man by another. Even a whole society, a nation, or even all simultaneously existing societies taken together, are not the owners of the globe. They are only its possessors, its usufructuaries, and, like boni patres familias, they must hand it down to succeeding generations in an improved condition" [28].

Contemporary political-economic and social research has also demonstrated that, contrary to mainstream economics which considers technology as an external and socially neutral factor, technology is in fact socially shaped and far from neutral. As I have elsewhere pointed out, "technology itself is the result of interaction among humans and between humans and nature, and is specifically shaped in a way crystallizing the main imperatives of the dominant capitalist mode of production" [14]. I have also argued that, technology, not in general, but as developed and directed within a capitalist context to serve capitalist profitability, "has played a particularly crucial role in ecological degradation and the society—nature metabolic rift" [14].

It should finally be noted that Marxist political economy is best suited, by considering capital as a social relation, to grasp the transnational expansion of capital and the transnational configuration of the relation between society and nature, moving afar from the artificially abstract and ossified conception of the "national economy" dominating mainstream economic thinking. This is not, of course, to deny the continuing, even if waning, significance of particular social formations or national states, but rather to problematize the dialectically contradictory relation between the national and the global, stressing that the transnational configuration of the society-nature relation is crucial for the exploration and understanding of the conditions of both social and ecological sustainability.

\section{The Capitalist Mode of Production and the People-Nature Relation under Capitalism}

This section is an attempt to outline the most specific features of the CMP and analyze their potential impact on environmental degradation and the ecological crisis we currently face on a planetary level. Among these features, we should take into account the following:

1 The specific character of the society - nature relation, and the capital — nature in particular, largely derives from the particular role of private property on land and natural resources. Contrary to a widely held belief, the implication is arguably that private property on land (or pricing the earth, according to a neoclassical proposal) cannot ensure an adequate environmental care, but rather, most usually leads to an overuse and destructive exploitation of natural resources. But even state ownership cannot ensure a rational coordination of the use of natural resources with social needs and an effective environmental protection insofar as the twin alienation of labour (see below), characterizing capitalism in all possible forms (including state capitalism), continues to have a decisive role in shaping the relation of people with nature. 
2 The competitive character of the CMP aiming at the production of exchange-values and not use-values meeting human needs, the associated growth obsession (or growth-mania), and the dominant goal of surplus value extraction and profit accumulation inherently lead, not only to an overexploitation of labour power, but also to a rapid depletion of natural resources and a planetary pollution putting the ecosystem at great risk.

3 The historically specific value form of labour and the specific character of capitalist valorization, which is exclusively based on the wage labour exploited and largely ignores the contribution of nature, while considering the natural forces utilized as "a free gift of nature to capital" [28], imply a potentially unlimited free appropriation of nature at essentially no cost $[21,23]$.

4 The inherently contradictory character of capital and market competition, by undermining community, common property and collective action, and ignoring social interdependence, implies a self-interested behaviour and an increasing externalization of production cost by private capital (negative externalities) [16,18]. As a consequence of this underestimation of cost, capital tends to over-expand its activities by exhausting productive resources, polluting the environment and shifting a major part of the cost to society.

5 Technology, as already noted, not in general, but as it is specifically shaped, directed and developed under capitalism should also be considered as a basic factor responsible for environmental degradation and the current ecological crisis. In this sense, technology, by serving the goals and the rationality of capital, simultaneously serves in exhaustively sucking the two fundamental sources of all wealth, as Marx put it, human labour power and nature [19].

These features of the CMP are crucial in explaining the currently exacerbating ecological crisis. The deeper causes of the currently faced ecological crisis should indeed be sought at systemic factors and tendencies, as the ones briefly outlined above, and not in the direction of a metaphysically conceived human nature or an abstract human behaviour in general [29]. In this sense, the deeper causes of ecological crisis have a historically specific, systemic and class character, which has to be taken into account seriously if we are to effectively face the problem. In the context of recent decades, the specific conditions of capitalist accumulation, by activating all these features or tendencies of the CMP, can largely explain both the exacerbated ecological crisis and its relation with the protracted and deepening economic (and social) crisis facing capitalism at a global scale.

\section{The Conditions and Prospects of Sustainability in Capitalism}

Beyond the basic characteristics of the CMP and their ecological implications outlined in the previous section, there is a further need to elucidate more specifically some important processes of capitalist development and explain those causal sequences that are largely responsible for the multifaceted and exacerbated ecological crisis. Such an analysis will be expedient for a somewhat more systematic exploration of the conditions and prospects of sustainability.

It should be noted, in the first place, that many societies in the past have been characterized by environmental degradation or led to a historical demise due to ecological crisis, and that ecological degradation is not a peculiar characteristic of capitalism. It can be argued, however, that, as the CMP has universal tendencies, it also leads to a universal ecological rift. The scale of ecological destruction is much larger under capitalism than under previous modes of production [10], and this is because of 
the totalizing tendency of the market mechanism [14], as well as the value augmentation and accumulation tendency in-built in the CMP itself, which implies an also augmenting energy and resource throughput and environmental damage.

Coming now to a more detailed explanation of this increasing ecological rift, we might stress that, under capitalism, an increase in labour productivity is essentially tantamount to a reduction in the amount of abstract socially necessary labour required for the production of any particular commodity (including labour power itself), which is a condition for an increased extraction and appropriation of surplus value [19]. This, as I have noted, is the dominant goal of capitalism, and hence all increases in the productivity of labour should serve this goal. Under this context, an increasing productivity of labour does not imply a process economizing on labour or any other productive resources. On the contrary, insofar as capital can proceed with a free appropriation of nature "as a gift to capital", there will be a permanent bias towards developing a labour-saving technology, but this technology is conducive to a maximum throughput of natural resources and energy, which further implies a rapidly increasing depletion of natural resources and an increasing pollution contributing to a systemic environmental degradation. A labour-saving technology, therefore, and a rising productivity of labour do not necessarily imply an increasing social and ecological efficiency, but rather an increasing potential for material and energy throughput, with an enhanced ecologically damaging impact. What is more, even a resource-saving technological innovation cannot have, under capitalism, an environmentally protective impact insofar as it will, most likely, imply lower commodity prices and hence an increasing market demand, which will result in an increased (rather than decreased) extraction of the natural resource concerned. This implication is clearly related with the so-called Jevon's Paradox [10,14,18].

Economic efficiency, at a societal level, is not simply a technical issue (a matter of input/output relation) and should not be understood, in general, as market (capitalist) efficiency. In fact it is largely determined, not only by the dominant goals of production, but also by the prevailing social relations and the scale of production, as well as relations of distribution and property regimes. Apart from other reasons, it should be noted that, insofar as negative externalities (cost shifting) are not taken into account and positive externalities are insufficiently utilized due to the fragmented and (individually) antagonistic character of capitalist production, a maximum social efficiency goal cannot be achieved under capitalism, and this has clear and significant ecological implications [14,16,18,23]. This would also largely apply within a context of "market socialism", but on this issue we will return below.

It should further be stressed that the expropriation and privatization of common property under contemporary capitalism has increased class tensions, economic inequality and environmental degradation, while mal-distribution and inequality undermine economic efficiency and the sustainability of production [16,17,30-32]. On the other hand, a large number of studies have recently questioned the assumed efficiency of private property and pointed out a remarkably efficient allocation and utilization of resources in some traditional or alternative property regimes, such as common property or open access regimes, which partly explains the long run sustainability of these regimes [18,31-34].

Despite this evidence, the rapid privatization and commodification of natural resources within the context of the current neoliberal and rapidly globalizing capitalism, along with the commodification of scientific research and technological innovation, tend to a detrimental and multifaceted ecological 
impact [35]. Among other forms of this ecological degradation, one might stress the rapid loss of biological diversity and the recent dramatic climate changes, as having far-reaching both ecological and economic implications. While this ecological degradation may imply an upward push of the regulating cost of production without immediately putting absolute barrier to the reproduction of capital, this process cannot continue without ultimately causing crucial and perhaps insurmountable economic and environmental problems.

Here, of course, we need to take into account the possibility of extending nature, of producing a "second nature" or alternative natures, which may have important implications for the sustainability of capitalism. There is an extensive research concerning this production of a "second nature" or alternative natures and their socioeconomic and ecological implications [29,36-38]. As E. Swyngedouw points out:

"While one sort of sustainability seems to be predicated upon feverishly developing new natures ... forcing nature to act in a way we deem sustainable or socially necessary, the other type is predicated upon limiting or redressing our intervention in nature, returning it to a presumably more benign condition so that human and non-human sustainability in the medium and long term can be assured. Despite the apparent contradictions of these two ways of 'becoming sustainable' (one predicated upon preserving nature's status quo, the other predicated upon producing new natures), they share the same basic vision that technonatural and sociometabolic interactions are urgently needed if we wish to secure the survival of the planet and much of what it contains" [39].

Although the possibility of producing new nature may extent the potential terrain of capitalist accumulation, and this may have important implication for an epoch characterized by a tendency towards a universal subsumption of nature under capital, it must be stressed that it does not imply that capitalism could ever escape all natural constraints. It is a rather limited and consequential potential [40].

Distinct from this potential of producing new nature, Neo-Malthusian approaches to the environmental problem, by assuming a finite availability of natural resources, have tended to overstress natural limits, presenting them usually in a naturalistic and absolute manner, while blaming overpopulation as the main source of environmental degradation and crisis [4,6]. On the other hand, Marx and contemporary Marxists, without ignoring natural and biological limits, conceive that social (organizational) or technological factors may, occasionally, relax or defer such limits. Reflecting on Marx's view, P. Burkett points out that, "with its exploitative scientific development of productive forces, its in-built tendency to 'reproduce itself upon a constantly increasing scale', and the attendant extension of production's natural limits to the global, biospheric level, capitalism is the first society capable of a truly planetary environmental catastrophe, one that could ultimately threaten even capital's own material requirements" [23]. As I have argued, referring to a particular example,

"The increasing water scarcity, the declining quality of water, and the inequitable pattern of its use across countries and in each particular country, along with a green-house warming that increasingly dries up mother earth, are not of course the result of some natural evolution, nor mainly the result of overpopulation, but rather an outcome of a few centuries of capitalist development and a particularly rapid economic growth during the last half of the twentieth century" [14].

In this case, as also in the case of energy, neo-Malthusian approaches are misleading insofar as they naturalize external limits (emphasizing natural scarcity), while largely ignoring the potentially 
important impact of drastic technological and organizational changes on both the supply and the demand side. On the latter side, quantitative and qualitative developments in social needs may be more the result of changes in technology and social organization, than the result of any population growth. But more importantly, neo-Malthusian approaches are misleading because they erroneously divorce the allocation of resources from the scale of production and, taking at face value the presumable allocative efficiency of the market mechanism, end up stressing a fixed scale of production and hence a steady-state model as a necessary condition for the sustainability of capitalism [41]. As R. Smith has plausibly argued, however, economic growth (and growthmania) is an inherent tendency of the market system and capitalism, and therefore a sustainability of capitalism through a steady-state adjustment is impossible [42].

It becomes rather clear from the preceding analysis and an increasing number of studies that capitalism, as a specific mode of production, tends to undermine the most basic conditions of ecological sustainability, jeopardizing thus the survival of human beings and of the capitalist system itself $[14,15,43,44]$. It would be rather misleading, however, to consider ecological sustainability separately from the conditions of economic and social sustainability of capitalism.

Although this is not the place to expand on the deeper causes of the currently evolving and aggravated economic crisis, which tends to directly and indirectly undermine the conditions of economic and social sustainability of capitalism, we should briefly take into account the fundamental role of the law of the tendency of the rate of profit to fall [28], lying behind the overaccumulation crisis of the early 1970s which continues, with some fluctuations, until the currently aggravated worldwide recession. This crisis, through a variety of processes and mechanisms, has fuelled the exacerbation of ecological crisis in various forms. Among these processes, we might consider the intensification of capitalist competition, the increasing externalities (cost-shifting), and the over-exhaustive exploitation of both labour power and natural resources. At the same time, there is an equally important dialectical feedback of the exacerbated ecological crisis on the further aggravation of economic and social crisis.

At this point it may be pertinent to briefly address the "dematerialization" hypothesis as it might possibly have significant implications for both ecological crisis (reduction of materials and energy use) and the economic crisis caused by a rising organic composition of capital, namely the relation between constant to variable capital $(\mathrm{C} / \mathrm{V})$, and falling profits rates (as noted above). According to this hypothesis, the increasing information and knowledge content of production in modern capitalism, along with a relative expansion of the sector of services and a more energy-efficient technology imply a significant reduction in the material requirements of production. There are good reasons however, to argue that this "dematerialization" has not any significant real dimensions [45,46]. More importantly, I would further argue that this presumable "dematerialization" trend cannot have a significant impact on the material requirements of production, negating the tendency towards a rising composition of capital. The capitalist imperatives behind this rising organic composition of capital relate to three interrelated processes. In the first place, any process of production in capitalism encompasses a use-value production and a valorization process, and labour has necessarily to be materialized through the use and transformation of energy and natural resources. Secondly, competition implies the need of an incessant mechanization and automation drive aiming at an increased labour productivity. Thirdly, the capitalist need to discipline and exploit labour in production can again be met by an increasing mechanization. This increasing mechanization requires increased energy and resource use and implies 
further a potentially maximum throughput of material resources with a minimum labour power. It follows, therefore, that these necessities cannot be significantly changed by any "dematerialization" trend, and hence it cannot have any significant ameliorating impact of economic and ecological crisis.

Capital, of course, deploys all sorts of strategies and methods to stave off or ameliorate crisis, and popular pressure may also have some effect in limiting the implications of economic and ecological crisis. Despite this pressure and all attempts or policies aiming at an ecological adjustment, however, it is rather impossible to adequately tackle the ecological problem within the context of the currently prevailing capitalist relations of production $[10,14,18,21]$. As the evidence available indicates, most of these attempts, aiming at a green redevelopment, dematerialization and a decoupling of capitalist economic growth from its negative ecological impact, have rather poor effects and cannot over all ensure the conditions for the sustainability of capitalism [46]. And as M. Singer notes, "although capitalism has produced an impressive array of technological innovations, as a global system it is characterized by inherent features that make it unsustainable and, further, that current efforts to implement green modifications to increase sustainability do not really address the central environment-society contradictions of this socioeconomic system" [44].

It becomes increasingly clear that the growing metabolic rift between society and nature, the exacerbated economic and ecological crisis, the expanding commodification of environmental goods and the rapid shrinkage of the public goods provision lead to an increasing degradation in the quality of life and undermine the required conditions for a sustainable human development [17,18,27]. While sustainable human development should be considered as being a major concern by itself and a crucial condition for the overall sustainability of society, mainstream theorizing and policy implementation regarding sustainable development are essentially concerned only with the sustainability of capitalist profitability (and growth), and not with the sustainability of the ecosystem or the conditions required for a sustainable human development. According to Burkett's interpretation of Marx, the intensification of the contradiction between production for profit and production for the satisfaction of human needs is a condition for capitalism's historical crisis, “[which] represents a generalized crisis of capitalist relations as a form of human-need satisfaction and human development, and this cannot be reduced to long-run profitability problems" [23]. It is such a crisis that we face today, which clearly manifests the economic, ecological and social un-sustainability of the capitalist mode of production.

The preceding analysis confirms our argument that a specific treatment of the social organization of production, which is essentially ignored by mainstream economics, is crucial for exploring the conditions of social and ecological sustainability. In light of the barriers to capitalist sustainability associated with the immanent features of the CMP, several researchers clearly point to the need for a historical transcendence of this particular mode of production [14,23,44,47]. The crucial question is, therefore, to envisage the appropriate social forces and transitional processes, as well as the specific organizational restructuring of society ensuring both social equity and sustainability, and ecological sustainability.

\section{Social Requirements for an Ecologically and Socially Sustainable Development}

Although it is beyond the limits of the present article to offer a detailed description of an alternative social organization, and both up-to-date social research and experience confirm that there are no ready- 
made and complete blueprints of such an alternative social organization transcending capitalism, a broad outline of the prerequisites for an ecologically and socially sustainable development is certainly required. There are good reasons (and a systemic, dialectical necessity) for such an alternative social organization to move on a socialist/communist trajectory, and this presupposes the abolition of private property and a supersession of commodity production, the market-imposed social division of labour, and the law of value itself.

For those advocating market socialism (such as Roemer, Schweickart, and others), the coordinating function of the market and its putative allocative efficiency can and should be disentangled from inequality of wealth and the dominant role of capitalism in the state, retaining the former within a market socialism regime [48]. It can be argued, however, that such a divorcing is practically impossible and historically unsustainable, mainly because the development itself of markets is essentially based on an inequality augmenting class differentiation (primitive accumulation), while markets in turn tend to increase inequality and reproduce capitalist relations of production. At the same time, a class dominated state, for as long as it exists, will continue to reinforce these developments. In other words, although markets may marginally exist independently of the CMP, a market society (with a dominant coordinating role of the market) is essentially indistinguishable from capitalism [49].

On the other hand, an important recent literature following an institutionalist approach stresses the advantages and the problem-solving potential of common property [30,31,33]. It is, however, a largely classless approach lacking a material background and specific account of the underlying social relations of production. These aspects are more specifically analyzed by a Marxist approach considering property under capitalism as largely a class and state mediated determination of nature appropriation, or an outcome of labour exploitation and crystallization of alienated labour. Within this context, class struggle provides the mechanism, not only for the determination of the conditions of labour exploitation, but also for social change and the restructuring or supersession of the prevailing property rights regime. Envisaging a communist perspective, Marx himself has argued that it will be only within a communal context that the associated producers will become capable of "rationally regulating their interchange with Nature ... achieving this with the least expenditure of energy and under conditions most favourable to, and worthy of, their human nature" [28]. Only in such a context, will conscious social planning enable associated producers to reverse the increasing metabolic rift and put an end to the havoc and anarchy of capitalism, creating at the same time the conditions for a truly human development [14,18,22,23]. This argument, however, in favour of social planning in general does not necessarily imply an advocacy of the stereotype of central planning usually associated with the collapsed regimes that were often considered as "actually existing socialism".

In the historical transition to full-fledged communist conditions, various forms of property regimes may be tested and perfected, including an open source regime and humanity heritage, localized or not common property, and so on. These property forms, along with collective action and a broad utilization of "reciprocity" and "subsidiarity" principles would entail a radical reorganization of the people-nature metabolism, allowing a socially equitable and sustainable co-evolution of society and nature.

As the reduction of socially necessary labour and the maximization of disposable free time constitute a basic principle of communism, there will be an inbuilt tendency to increase social efficiency [28,49]. It can be moreover argued that, under these conditions, an increase in labour 
productivity would not imply resource depletion (as is the case under capitalism) insofar as production is targeted on use-value and not on exchange value and a maximization of profit or capitalist growth. It would rather imply that certain social needs can be met with the expense of less labour time and most likely of fewer natural resources insofar as science and technology can serve in economizing on the material inputs of production. As I have more specifically argued, contrary to the accepted view of a generalized abundance in communism, "scarcity can be relativized and substantially reduced, through the development of productive forces, the development of science and technology, and a radical change of social relations, but in a world of finite (non-renewable) resources it cannot be totally eliminated" [21,49]. However, the efficient allocation and utilization of both labour forces and natural resources will be ensured, not by any purely economic mechanism such as the market, but through sociopolitical deliberation and participative planning. In this case, participative planning means that any process of deliberation or planning should be undertaken with an initiative and essential control "from below", namely from the associated producers and citizens involved. Within such a context, it is to be expected that there will be a socially rational determination of the precise conditions of ecological and social sustainability, as well as an adequate implementation of these conditions.

Without overstressing a localized organization at the expense of a broader socioeconomic coordination, it should also be noted that, decentralization and small scale production would also allow for a precious ecological diversification and cultural pluralism [18,34,50].

As I have elsewhere pointed out, "If the dispossession of labour of natural resources and means of subsistence (the negation) leads to labour's alienation and estrangement from nature, and at the same time creates the preconditions of (wage) labour exploitation and alienation within the labour process, then the abolition of private property on nature (the negation of the negation) is a precondition for superseding this twin alienation of labour" [14]. Such a radical transformation, of course, can be brought about only through a revolutionary overturn of the fetishized "inverted world" of capitalism to stand society on its feet and ensure a twin emancipation of labour (from nature estrangement and wage labour exploitation) and a reconciliation of society with nature at a higher level [18,23,47]. Although such a revolutionary overturn may seem a daunting task, the astonishing exacerbation of both socioeconomic and ecological crisis makes it increasingly a convincing case and a more realistic task than the fake expectation that a truly sustainable development may be achieved within the context of the existing capitalist system.

\section{Acknowledgements}

I am grateful to Sustainability editors and the anonymous reviewers of the journal for useful comments on an earlier draft of this article.

\section{References}

1. The Sustainable Development Paradox: Urban Political Economy in the United States and Europe; Krueger, R., Gibbs, D., Eds.; Guilford Press: New York, NY, USA, 2007.

2. Harris, J.M. Environmental and Natural Resource Economics: A Contemporary Approach, 2nd ed.; Houghton Mifflin: Boston, MA, USA, 2006; pp. 33, 472-473.

3. Lélé, S. Sustainable development: A critical review. World Develop. 1991, 19, 607-621. 
4. Daly, H. Beyond Growth: The Economics of Sustainable Development; Beacon: Boston, MA, USA, 1996.

5. Bromley, D. Environmental regulations and the problem of sustainability: Moving beyond "market failure". Ecol. Econ. 2007, 63, 676-683.

6. Jackson, T. Prosperity without Growth; Earthscan: London, UK, 2009.

7. Redclift, M. Sustainable Development: Exploring the Contradictions; Methuen: London, UK, 1987.

8. Rees, W.E. The ecology of sustainable development. Ecologist 1990, 20, 18-23.

9. Foster, J.B. Ecology and human freedom. Mon. Rev. 1995, 47, 22-31.

10. Castro, C. Sustainable development: Mainstream and critical perspectives. Organ. Environ. 2004, 17, 195-225.

11. Just Sustainabilities: Development in an Unequal World; Agyeman, J., Bullard R., Evans B., Eds.; MIT Press: Cambridge, MA, USA, 2003.

12. Robbins, L. An Essay on the Nature and Significance of Economic Science; Macmillan: London, UK, 1952.

13. Heilbroner, R.; Milberg, W. The Making of Economic Society; Prendice Hall: New York, NY, USA, 2006.

14. Liodakis, G. Totalitarian Capitalism and Beyond; Ashgate Publishing: Surrey, UK, 2010.

15. Perelman, M. Myths of the market: Economics and the environment. Organ. Environ. 2003, 16, 168-226.

16. Swaney, J. Common property, reciprocity, and community. J. Econ. Issue. 1990, 24, 451-462.

17. Bollier, D. Silent Theft: The Private Plunder of Our Common Wealth; Routledge: London, UK, 2003.

18. Burkett, P. Marxism and Ecological Economics: Toward a Red and Green Political Economy; Brill Academic Publishers: Boston, MA, USA, 2006.

19. Marx, K. Capital I; International Publishers: New York, NY, USA, 1967; pp. 507, 509, 737, 762.

20. Harvey, D. The New Imperialism; Oxford University Press: Oxford, UK, 2003.

21. Liodakis, G. The people-nature relation and the historical significance of the labour theory of value. Capital Class 2001, 73, 113-140.

22. Foster, J.B. Marx's Ecology: Materialism and Nature; Monthly Review Press: New York, NY, USA, 2000; pp. 152-154.

23. Burkett, P. Marx and Nature: A Red and Green Perspective; Macmillan: London, UK, 1999; pp. 68-78, 194-197.

24. Lodziak, C. Manipulating Needs: Capitalism and Culture; Pluto Press: London, UK, 1995.

25. Smith, A. An Inquiry into the Nature and Causes of the Wealth of Nations; Clarendon Press: Oxford, UK, 1976; p. 155.

26. Marx, K. Grundrisse; Vintage Books: New York, NY, USA, 1973; pp. 83-108.

27. Clark, B.; York, R. Rifts and shifts: Getting to the root of environmental crises. Mon. Rev. 2008, 60, 13-24.

28. Marx, K. Capital III; International Publishers: New York, NY, USA, 1967; pp. 745, 776, 812, 820.

29. O’Connor, J. Natural Causes: Essays in Ecological Marxism; Guilford Press: New York, NY, USA, 1998. 
30. Allen, R.C. The efficiency and distributional implications of 18th century enclosures. Econ. J. 1982, 92, 937-953.

31. Runge, C.F. Common property and collective action in economic development. World Develop. 1986, 14, 623-635.

32. O’Neill, J. Property, care, and environment. Environ. Plan. C-Gov. Policy 2001, 19, 695-711.

33. Ostrom, E. Collective action and the evolution of social norms. J. Econ Perspect. 2000, 14, 137-158.

34. O’Neill, J. Markets, Deliberation and Environment; Routledge: London, UK, 2007.

35. Liodakis, G. The role of biotechnology in the agro-food system and the socialist horizon. Hist. Mat. 2003, 11, 37-74.

36. Smith, N. Uneven Development: Nature, Capital and the Production of Space; Blackwell: Oxford, UK, 1984.

37. Castree, N. The nature of produced nature: Materiality and knowledge construction in Marxism. Antipode 1995, 27, 12-48.

38. Dickens, P. Reconstructing Nature: Alienation, Emancipation and the Division of Labour; Routledge: London, UK, 1996.

39. Swyngedouw, E. Impossible "Sustainability" and the Political Condition; Krueger, R., Gibbs, D., Eds.; Guilford Press: New York, NY, USA, 2007.

40. Wallis, V. Capitalist and socialist responses to the ecological crisis. Mon. Rev. 2008, 60, 25-40.

41. Burkett, P. Entropy in ecological economics: A marxist intervention. Hist. Mat. 2005, 13, 117-152.

42. Smith, R. Beyond growth or beyond capitalism? Real-world Econ. Rev. 2010, 53, 28-42.

43. O’Connor, M. Is Capitalism Sustainable? The Guilford Press: London, UK, 1994.

44. Singer, M. Economics: Are the planet-unfriendly features of capitalism barriers to sustainability? Sustainability 2010, 2, 127-144.

45. Trainer, T. The "de-materialisation" myth. Technol. Soc. 2001, 23, 505-514.

46. Næss, P.; Høyer, G. The emperor's green clothes: Growth, decoupling, and capitalism. Capital. Nat. Social. 2009, 20, 74-95.

47. Sheasby, W. Inverted world: Karl marx on enstrangement of nature and society. Capital. Nat. Social. 1997, 8, 31-47.

48. Market Socialism: The Debate among Socialists; Ollman, B., Ed.; Routledge: New York, NY, USA, 1998.

49. McNally, D. Against the Market: Political Economy, Market Socialism and the Marxist Critique; Verso: London, UK, 1993; pp. 190-193, 206, 212.

50. Shiva, V. Earth Democracy. In New Socialisms: Futures Beyond Globalization; Albritton, R., Bell, S., Westra, R., Eds.; Routledge: London, UK, 2004; pp. 53-70.

(C) 2010 by the authors; licensee MDPI, Basel, Switzerland. This article is an Open Access article distributed under the terms and conditions of the Creative Commons Attribution license (http://creativecommons.org/licenses/by/3.0/). 